\title{
Study on the Revitalization Potential of Thermal-treated Soils
}

\author{
L. VERMES and B. BIRÓ \\ Szent Istvan University, Faculty of Horticultural Sciences, Budapest, and \\ Research Institute for Soil Science and Agricultural Chemistry (RISSAC) of the \\ Hungarian Academy of Sciences, Budapest
}

The revitalization of soils that have become microbiologically sterile due to some reason is an important task for ecologists (DOUBLEDAY, 1974), especially on contaminated sites. This situation creates several technologies for soil remediation, such as thermal treatments, where after the extremely high temperature it is a requirement to make the soil susceptible again for plant cultivation and growth.

There are several methods of revitalization. Frequently inorganic fertilizers are given for improving plant growth and reestablishment. Due to the lack of organic materials, farmyard manure, composts or detoxificated sewage sludge might be applied regularly (SCULLION, 1992). The combination of both methodologies was also reported and an improvement of fertility was found after an 8- and 15-year recultivation practice (BIRÓ et al., 1993a). Fertilizer application alone could also enhance the development and functioning of natural symbiosis in intensive agricultural systems (BIRÓ et al., 1993b, KÁTAI 1999). There is, however, a great necessity to learn more about the interaction between soil-life, the various microbial populations and the different soil biotic and abiotic factors. Knowledge of the population levels of these microbiologically degraded soils is thus especially important when planning the reclamation and recultivation strategy.

For studying the revitalization possibilities of such sterile soils a pot experiment was carried out at the Experimental Farm of the Faculty of Horticultural Sciences of the Szent István University in 2001. The aim of the experiment was to investigate the effects of a) different organic and inorganic materials, b) microbial inocula preparations, and c) their combinations, in order to achieve faster and safer revitalization practice on the thermal-treated polluted soil.

Correspondence to: Dr. László VERMES, Szent István University, Faculty of Horticultural Sciences, Department of Soil Science and Water Management, H-1114 Budapest, Villányi út 35-43. Hungary. E-mail: lvermes@omega.kee.hu 


\section{Materials and Methods}

Soil treatments and additives. - A pot experiment, with two factors and four replicates, was carried out in greenhouse to study the effect of different additives on the thermal-treated soil. Other cultivation substances were also added to them, so as to improve the revitalization success of these substrates and the growth of the Brassica napus DC test plants. Preliminary thermal treatment of the soils was conducted in two $\mathrm{kg}$ containers for 4 hours at 350,250 and $170{ }^{\circ} \mathrm{C}$ (treatment $\mathrm{C} 1, \mathrm{C} 2$ and $\mathrm{C} 3$, respectively). Growth of the test plant was also investigated in $\mathrm{C} 2$ substrates with clay-pearl (A1) and perlite (A2) addition $(2: 1=$ $\mathrm{v}: \mathrm{v})$. The non-treated, absolute control soil was labelled as E1. The main characteristics of the soils used in the experiment are shown in Table 1.

Table 1

Main characteristics of the soils used in the pot experiment (2001)

\begin{tabular}{|l|c|c|c|c|}
\hline \multirow{2}{*}{\multicolumn{1}{c|}{$\begin{array}{c}\text { Soil } \\
\text { characteristics }\end{array}$}} & \multicolumn{3}{|c|}{ In soil treated at } & Non-treated \\
\cline { 2 - 4 } & $170{ }^{\circ} \mathrm{C}(\mathrm{C} 3)$ & $250^{\circ} \mathrm{C}(\mathrm{C} 2)$ & $350{ }^{\circ} \mathrm{C}(\mathrm{C} 1)$ & \\
sH & 9.32 & 7.95 & 7.82 & 8.10 \\
Total salt, \% & 0.08 & 0.15 & 0.19 & 0.12 \\
$\mathrm{Humus}^{*} \%$ & 0.27 & 0.79 & 1.25 & 2.58 \\
$\mathrm{~K}_{\mathrm{A}}{ }^{*}$ & 40 & 30 & 37 & 37 \\
$\mathrm{NO}_{3}-\mathrm{N}, \mathrm{mg} / \mathrm{kg}$ & 5.07 & 2.13 & 8.64 & 3.32 \\
$\mathrm{P}_{2} \mathrm{O}_{5}, \mathrm{mg} / \mathrm{kg}$ & 188 & 221 & 288 & 485 \\
$\mathrm{~K}_{2} \mathrm{O}, \mathrm{mg} / \mathrm{kg}$ & 344 & 105 & 109 & 202 \\
$\mathrm{Ca}, \%$ & 2.60 & 0.50 & 1.10 & 0.89 \\
$\mathrm{Mg}, \mathrm{mg} / \mathrm{kg}$ & 255 & 70.7 & 142 & 155 \\
$\mathrm{Fe}, \mathrm{mg} / \mathrm{kg}$ & 50.3 & 92.3 & 9.18 & 48.5 \\
$\mathrm{Mn}, \mathrm{mg} / \mathrm{kg}$ & 18.5 & 71.0 & 183 & 23.9 \\
$\mathrm{Zn}, \mathrm{mg} / \mathrm{kg}$ & 2.47 & 8.82 & 1.09 & 6.65 \\
$\mathrm{Cu}, \mathrm{mg} / \mathrm{kg}$ & 1.69 & 5.78 & 2.16 & 1.93 \\
$\mathrm{CaCO}, \%$ & 14.7 & 0.42 & 4.20 & 3.57 \\
\hline
\end{tabular}

$* \mathrm{~K}_{\mathrm{A}}=$ Upper limit of plasticity according to Arany (In: BuZÁs, 1988)

The cultivation substrates, mentioned above were treated with different inorganic and organic additives, such as: fertilizer (II: $100-100 \mathrm{~kg} \mathrm{ha}^{-1} \mathrm{~N}, \mathrm{P}, \mathrm{K}$ active ingredients) stabile manure (III) and compost (IV) $(3: 1=\mathrm{v}: \mathrm{v})$, alga (I) or fullstrength microbial inocula $(\mathrm{V})$, and/or their mixtures $(\mathrm{VI}=\mathrm{II}+\mathrm{V}$, VII $=\mathrm{III}+\mathrm{V}$, VIII $=\mathrm{IV}+\mathrm{V})$, using a non-treated control (E1).

Microbial inoculation. - Different Cyanobacteria isolates were selected from a natural brown forest soil (SZEGI, 1979). After their typization the antagonistic ability was tested in vitro. A mixture of the most antagonistic 4 strains was used for the inoculation. After a one-week growth on light, $10 \mathrm{~cm}^{3}$ inoculum was used in each pot of the algal treatment. 
Full-spectrum microbial suspension was prepared from a ripened compost material by a dilution technique. $500 \mathrm{~g}$ compost was mixed with $1000 \mathrm{ml}$ distilled water and shaken for 30 minutes. This suspension was used for upscaling the microbial inoculum in a sucrose enriched nutrient solution (SZEGI, 1979) 24 hours growth at room temperature. After an approximately $10^{8} \mathrm{CFU} \mathrm{\textrm {cm } ^ { 3 ( - 1 ) }}$ propagulum number, $10 \mathrm{~cm}^{3}$ inoculum was applied to the treated pots after sowing.

Plant growth assessment. - Ten seeds of Brassica napus DC were sown in $1 \mathrm{~kg}$ pots in May 2001. Each treatment - with 4 replicates - was randomly arranged in the greenhouse. Seed germination was assessed after the emergence and plant height was measured in the pots 5 times during the vegetation period. Means of the data and significant differences (data not shown) were calculated for each treatment.

Plant sampling was performed 5 times during the vegetation period. Green yields of shoot and root were measured and, after drying for the constant weight, the dry mass production was determined. Soil samples were taken from the treatments to determine the organic matter $(\mathrm{OM})$ and the nitrogen content (BUZÁs, 1988) at the end of the vegetation period.

Statistical analysis. - Results were analyzed and evaluated with the help of the SPSS statistical program package, using single way analysis (ANOVA). The type of evaluation is statistical calculation, from single cases, so as to draw conclusions about the accuracy of the results.

\section{Results and Discussion}

Data on the mean of plant height and green yield, the humus and nitrogen content of the soils measured at the end of the vegetation period are presented in Table 2.

\section{Germination and plant performance}

The positive effect of stable manure (Treatment III) on plant growth and development can be seen in Table 2, especially at the highest thermal treatment. Not only germination, but plant vigour (colour of the leaves) and the green biomass were also improved. Moreover the soil parameters (humus and $\mathrm{N}$ content) investigated were also positively affected.

Perlite addition (A2) to the soils did not really result in a significant positive effect. At the early stage of the experiment the perlite treatments improved germination and the plant number in the pots, but later this positive effect could not be proven. 
Table 2

Mean data of plant height and green yield of Brassica napus DC, the humus- and nitrogen content of the soils of the pot experiment measured at the end of the vegetation period

\begin{tabular}{|c|c|c|c|c|c|c|}
\hline \multirow{2}{*}{$\begin{array}{c}\text { Substrate/ } \\
\text { Thermal } \\
\text { treatment }\end{array}$} & \multirow{2}{*}{$\begin{array}{l}\text { Organic, } \\
\text { inorganic } \\
\text { additives }\end{array}$} & \multirow{2}{*}{$\begin{array}{c}\text { Plant } \\
\text { height, } \\
\mathrm{cm}\end{array}$} & \multirow{2}{*}{$\begin{array}{c}\text { Green } \\
\text { yield, } \\
\text { G }\end{array}$} & $\begin{array}{c}\text { Humus } \\
\%\end{array}$ & $\begin{array}{l}\mathrm{N} \\
\%\end{array}$ & $\begin{array}{l}\mathrm{C} / \mathrm{N} \\
\text { ratio }\end{array}$ \\
\hline & & & & \multicolumn{3}{|c|}{ in soil } \\
\hline \multirow[t]{6}{*}{ A1 } & III. & 26.63 & 7.99 & 3.22 & 0.42 & 7.52 \\
\hline & IV. & 33.60 & 19.27 & 2.86 & 0.15 & 18.91 \\
\hline & V. & 16.61 & 3.58 & 1.42 & 0.08 & 18.17 \\
\hline & VI. & 22.02 & 11.01 & 3.85 & 0.42 & 9.23 \\
\hline & VII. & 32.66 & 24.86 & 3.13 & 0.55 & 5.65 \\
\hline & VIII. & 19.45 & 24.35 & 1.32 & 0.12 & 11.24 \\
\hline \multirow[t]{6}{*}{$\mathrm{A} 2$} & III. & 22.72 & 11.88 & 3.42 & 0.15 & 22.21 \\
\hline & IV. & 29.09 & 17.72 & 2.56 & 0.56 & 4.50 \\
\hline & V. & 28.86 & 8.90 & 1.71 & 0.06 & 30.61 \\
\hline & VI. & 29.32 & 14.76 & 2.72 & 0.28 & 9.61 \\
\hline & VII. & 31.60 & 18.78 & 2.96 & 0.41 & 7.41 \\
\hline & VIII. & 43.85 & 11.34 & 1.56 & 0.13 & 11.63 \\
\hline \multirow[t]{6}{*}{$\mathrm{C} 1$} & III. & 21.49 & 8.77 & 4.51 & 1.42 & 3.17 \\
\hline & IV. & 30.25 & 18.59 & 4.01 & 0.64 & 6.28 \\
\hline & V. & 15.21 & 3.14 & 2.79 & 0.11 & 24.33 \\
\hline & VI. & 24.00 & 11.17 & 4.93 & 0.51 & 9.73 \\
\hline & VII. & 38.08 & 24.26 & 4.57 & 0.68 & 6.72 \\
\hline & VIII. & 25,80 & 21.69 & 2.06 & 0.25 & 8.17 \\
\hline \multirow[t]{7}{*}{$\mathrm{C} 2$} & I. & 26.08 & 11.50 & 3.67 & 0.06 & 29.60 \\
\hline & III. & 27.23 & 13.29 & 3.86 & 0.47 & 8.20 \\
\hline & IV. & 35.91 & 17.16 & 3.19 & 0.32 & 9.82 \\
\hline & V. & 29.16 & 28.65 & 1.72 & 0.24 & 7.21 \\
\hline & VI. & 25.51 & 19.89 & 4.22 & 0.29 & 14.78 \\
\hline & VII. & 36.80 & 18.65 & 3.67 & 0.55 & 6.63 \\
\hline & VIII. & 22.19 & 8.75 & 1.43 & 0.25 & 5.61 \\
\hline \multirow[t]{6}{*}{ C3 } & III. & 37.60 & 25.33 & 3.22 & 0.31 & 10.18 \\
\hline & IV. & 33.18 & 30.28 & 2.16 & 0.27 & 8.03 \\
\hline & V. & 30.66 & 14.34 & 0.37 & 0.15 & 2.48 \\
\hline & VI. & 31.73 & 15.27 & 3.15 & 0.21 & 14.79 \\
\hline & VII. & 35.35 & 30.34 & 2.04 & 0.21 & 9.48 \\
\hline & VIII. & 42.48 & 40.85 & 0.36 & 0.10 & 3.59 \\
\hline E1 & VIII. & 25.44 & 17.69 & 2.27 & 0.31 & 7.37 \\
\hline
\end{tabular}

Remarks: Substrate/Thermal treatments: $\mathrm{A} 1=$ clay-pearl; $\mathrm{A} 2=$ perlite; $\mathrm{C} 1=350{ }^{\circ} \mathrm{C}$; $\mathrm{C} 2=270{ }^{\circ} \mathrm{C} ; \mathrm{C} 3=170{ }^{\circ} \mathrm{C}$ heat treatments of soil; $\mathrm{E} 1=$ untreated, non-heated soil. Additives: I: alga treatment; III: manure; IV: compost; V: additional microbial inoculum; VI: fertilizer + inoculation; VII: manure + inoculation; VIII: compost + inoculation 
Among the soils with different heat treatments $(\mathrm{C} 1-\mathrm{C} 3)$ there were no great differences in the total germination rate and green biomass in the early stage of the vegetation period, however, later they became highly affected. A simultaneous decrease in almost all parameters was found with the increase of heattreatment of soils. In case of plant vigour (leaf colour), no such tendency was detected.

The addition of compost (IV) had no influence on the germination of plants, but it positively affected green yield data. The strongest positive effect was observed in the case of leaf colour. The significant increase of plant height and soil nitrogen content support the addition of this organic material into various thermal-treated soils.

Addition of clay-pearl had a negative influence only on germination, later several parameters improved during the soil revitalization. The usage of microbial inocula $(10 \mathrm{ml} / \mathrm{pot})$ into the substrates protected the seedlings from drought and stress. The plants could survive better on the different soils and substrates. The greatest influence was detected in respect of the $\mathrm{C} / \mathrm{N}$ ratio of soils. The ratio increased considerably with the combined addition of compost and inoculum. With the increase in nitrogen uptake by plants, the soil nitrogen content decreased. A detectable effect was also found in plant colour, as well.

\section{Plant heights at the end of the experiment}

Plant height and stem length are the most typical parameters of plant growth. According to Table 3, the best plant height data could be observed in the $\mathrm{C} 3$ $\left(170{ }^{\circ} \mathrm{C}\right.$ heat-treated) and the A2 (perlite) treatments. The worst result was obtained in the $\mathrm{C} 1$ treatment, which expresses the negative effect of the $350{ }^{\circ} \mathrm{C}$ heat treatment of soils.

More useful information can be obtained with statistical evaluation. Further analysis showed that the most effective treatment was VII, with a total value of more than $30 \mathrm{~cm}$ plant height. In these pots a combined organic manure and microbial inocula (originating from the compost) was added to the soils.

Table 3

Mean data of plant height (cm) of Brassica napus DC in the pot experiment (2001)

\begin{tabular}{|c|c|c|c|c|c|}
\hline $\begin{array}{c}\text { Organic, } \\
\text { inorganic } \\
\text { additives }\end{array}$ & $\begin{array}{c}\mathrm{A} 1 \\
\text { Clay-pearl } \\
\text { substrate }\end{array}$ & $\begin{array}{c}\mathrm{A} 2 \\
\text { Perlite } \\
\text { substrate }\end{array}$ & $\begin{array}{c}\mathrm{C} 1 \\
350{ }^{\circ} \mathrm{C} \\
\text { treated soil }\end{array}$ & $\begin{array}{c}\mathrm{C} 2 \\
270^{\circ} \mathrm{C} \\
\text { treated soil }\end{array}$ & $\begin{array}{c}\mathrm{C} 3 \\
170{ }^{\circ} \mathrm{C} \\
\text { treated soil }\end{array}$ \\
\hline III. & 26.63 & 22.72 & 21.49 & 27.23 & 37.60 \\
IV. & 33.60 & 29.09 & 30.25 & 35.91 & 33.18 \\
V. & 16.61 & 28.86 & 15.21 & 29.16 & 30.66 \\
VI. & 22.02 & 29.32 & 24.00 & 25.51 & 31.73 \\
VII. & 32.66 & 31.60 & 38.08 & 36.80 & 35.35 \\
VIII. & 19.45 & 43.85 & 25.80 & 22.19 & 42.48 \\
\hline
\end{tabular}

For organic and inorganic additives: See Table 2. Value of the untreated control is: 25.44. 
The maturated compost - enriched with the microbial inocula (treatment VIII) - can also develop a rapid and effective way of revitalization. In the thermal-treated soils it can supply the nutrients and replace or increase the organic matter content. By creating the necessary, but missing microflora, it is possible in such a way to improve soil fertility. The beneficial effect of organic additives + inoculum treatment showed, therefore that the strongly heated, structurally and chemically destroyed, dead "soils" can also be revitalized successfully.

Compost addition (without inoculum enrichment) could result a positive effect in the treatments. The other organic additive, stable manure (III) was found to be less beneficial to the parameters investigated. The addition of inoculum to manure, however resulted a further improvement of plant height (treatment VII). Microbial inocula, as single treatment without organic additives (V) was not successful enough for the remediation/revitalization of heat-treated soils.

\section{Green yield of the test plants}

Biomass production is one of the most important parameters of plant growth. The mean yields of the test plants were calculated for the treated pots and the results are given in Table 4. These data showed that the highest green yields were found on the substrate with the lowest heat treatment. A much lower efficiency was realized, therefore at the highest heat treatment. The differences in green yield among the treatments were smaller than those of plant heights.

In case of a further analysis of the different treatments, a more useful conclusion can be drawn. Using the earlier numerical values for the green yield data, the compost + inocula treatment (VIII) was found to be the most effective. This result is in agreement with the plant height data, as it has already been pointed out. The other valuable treatment is the single compost addition (treatment IV). The parallel addition of clay-pearls and perlite mixture was also effective in the $250{ }^{\circ} \mathrm{C}$ treated soil. It is also obvious from the results that the farmyard manure, and the manure + inocula treatments can provide acceptable

Table 4

Mean data of the green yield of Brassica napus DC in the pot experiment

\begin{tabular}{|c|c|c|c|c|c|}
\hline $\begin{array}{c}\text { Organic, } \\
\text { inorganic } \\
\text { additives }\end{array}$ & $\begin{array}{c}\mathrm{A} 1 \\
\text { Clay-pearl } \\
\text { substrate }\end{array}$ & $\begin{array}{c}\mathrm{A} 2 \\
\text { Perlite } \\
\text { substrate }\end{array}$ & $\begin{array}{c}\mathrm{C} 1 \\
350{ }^{\circ} \mathrm{C} \\
\text { treated soil }\end{array}$ & $\begin{array}{c}\mathrm{C} 2 \\
270{ }^{\circ} \mathrm{C} \\
\text { treated soil }\end{array}$ & $\begin{array}{c}\mathrm{C} 3 \\
170^{\circ} \mathrm{C} \\
\text { treated soil }\end{array}$ \\
\hline III. & 7.99 & 11.88 & 8.77 & 13.29 & 25.33 \\
IV. & 19.27 & 17.72 & 18.59 & 17.16 & 30.28 \\
V. & 3.58 & 0.90 & 0.14 & 8.65 & 14.34 \\
VI. & 11.01 & 7.99 & 11.17 & 19.89 & 15.27 \\
VII. & 24.86 & 18.78 & 24.26 & 18.65 & 30.34 \\
VIII. & 24.35 & 11.34 & 21.69 & 28.75 & 40.85 \\
\hline
\end{tabular}

For organic, inorganic additives: See Table 2. Value of the untreated control (E1) is: 17.69. 
results in the revitalization processes. All other data, such as the microbiological survey further strengthen these above-mentioned results.

\section{Microbial parameters of the treated soils}

The results of microbiological investigations are summarized in Table 5. Clay-pearl treatments (A1) had an especially positive effect on microbial activ-

Table 5

Total number* of microbes, micromycetes and Actinomycetes in the treated soils of the pot experiment (2001)

\begin{tabular}{|l|l|l|l|l|l|l|l|l|}
\hline \multirow{2}{*}{} & \multirow{2}{*}{ Microbes } & \multicolumn{7}{|c|}{ Microbial abundance $\left(\log _{10} \mathrm{~g}^{-1}\right.$ d.w.) in treatments } \\
\cline { 2 - 8 } A1 & Total microbes & & 7.39 & 7.63 & 8.56 & 7.88 & 6.84 & 7.80 \\
& Micromycetes & & 4.60 & 6.30 & 5.55 & 4.63 & 5.06 & 5.72 \\
& Actinomycetes & & 6.76 & 8.08 & n.d. & 6.86 & 6.23 & 6.02 \\
A2 & Total microbes & & 7.37 & 7.34 & 7.76 & 7.46 & 7.51 & 6.84 \\
& Micromycetes & & 4.49 & 5.67 & 4.52 & 5.19 & 5.94 & 4.00 \\
& Actinomycetes & & 6.40 & 6.25 & 6.64 & 6.77 & 6.54 & 6.47 \\
C1 & Total microbes & & 6.97 & 6.72 & 6.48 & 7.36 & 6.56 & 6.23 \\
& Micromycetes & & 4.37 & 4.86 & 4.81 & 4.84 & 4.35 & 4.43 \\
& Actinomycetes & & 6.59 & 5.74 & n.d. & 6.33 & 6.72 & n.d. \\
C2 & Total microbes & 9.60 & 7.57 & 8.52 & 7.58 & 7.63 & 6.50 & 8.56 \\
& Micromycetes & 6.87 & 5.86 & 5.92 & 5.75 & 5.88 & 6.56 & 4.06 \\
& Actinomycetes & 6.71 & 6.42 & n.d. & 6.61 & 6.83 & n.d. & 6.46 \\
C3 & Total microbes & & 8.58 & 7.55 & 8.34 & 8.04 & 8.18 & 8.70 \\
& Micromycetes & & 5.78 & 5.07 & 5.58 & 4.85 & 4.75 & 6.35 \\
& Actinomycetes & & 6.56 & 6.60 & 6.46 & 6.68 & 6.66 & 6.65 \\
E1 & Total microbes & & & & & & & 8.53 \\
& Micromycetes & & & & & & & 5.58 \\
& Actinomycetes & & & & & & & n.d. \\
\hline
\end{tabular}

Remarks: * colony forming units (CFU g ${ }^{-1}$ dry soil); For treatments: see Table 2

ities. The abundance of all microbial types could be increased with the addition of such clay materials.

The number of total countable microbes was significantly enhanced by the microbial inoculation treatments in comparison to the addition of farmyard manure or compost. The number of filamentous fungi (micromycetes) was low in the farmyard manure and almost 100-times more (2-fold increase) in the composted material. In case of the liquid fermentation of the microbial inocula, micromycetes were not able to produce a good growth. That is perhaps the reason for their failure and lesser activity. 
The success of microbial inoculations was assessed in the soil substrates, after a 4-hour heat treatment at 350,250 and $170{ }^{\circ} \mathrm{C}$. The main groups of culturable microbes, such as the total colony-forming units (CFU), micromycetes and Actinomycetes were counted on selective plates with differential media. The less abundance (1- or 2-fold decrease) of culturable microbes was found when the soil was heat-treated at $350{ }^{\circ} \mathrm{C}$. The detected results, however, differed as a function of the type of microbial group, investigated. As it can be seen in Table 5, total microbes grown on the nutrient plates were greater in number at the lowest temperature treatment. Micromycetes, however better preferred the highest temperature treatment of the soil substrates. Their abundance reached the maximum at $250{ }^{\circ} \mathrm{C}$, with the exception of the substrate with compost addition. The third microbial group, the Actinomycetes, was not sensitive to the heat treatment of soil. In all substrates, either both with inorganic or organic additives their numbers were rather stabile (between 6.33 and 6.83), with no significant difference.

Among the organic additives, compost proved to be more acceptable for promoting the success of revitalization. In case of all microbial groups, the highest number was found generally in case of compost amendments. Somewhat similar results were published by INSAM \& DOMSCH (1988). The countable number of micromycetes proved to be especially high in the composted material (2-fold increase, which means a 100-times higher amount). Composting processes therefore can contribute to soil revitalization to a great extent. The inoculum used also originated from the compost, with the exception of the alga treatment. The mixture of blue- and green alga-strains was selected from the original, not-treated soil. Their effect, however, with the inoculation was not found to be significantly positive. Although the alternative application of alga treatments is currently being suggested as soil nutrient $(\mathrm{P})$ indicators (ÖRDÖG \& MÁTÉ, 2002), their abundance did not reflect soil quality in this study. For the revitalization purpose, therefore only a permanent algal treatment can make a positive contribution to soil revitalization and fertility.

\section{Summary}

A pot experiment was set up at the Experimental Farm of the Faculty of Horticultural Sciences of the Szent István University in 2001 investigating the revitalization effect of selected treatments on thermal-treated soils and other production substances. In the experiment 6 factors and 7 treatments were used, each in 4 replicates, using rape (Brassica napus DC) as test plant. During the time period of the experiment (29 May-17 August) continuous observations and measurements were conducted, plant and soil analyses - chemical and microbiological - were made to establish the main effects and results of the different treatments. These are discussed in the paper in detail. 
Although the soil-vitalization procedures were of great success, no treatment in the experiment had an extremely positive effect. Various additives, however could enhance the re-colonization processes significantly.

According to the basic factors (the soils or substrates) the best treatments were: the A1 (clay-pearl) additive and the $\mathrm{C} 2, \mathrm{C} 3$ factors (the medium and low temperature soil treatments).

Among the treatment combinations, treatments IV and VII were the best (compost and compost + inocula addition). This fact shows that the compost in a good quality, and the compost enriched, compost extracted microbial inocula can play the most important role in the revitalization of thermal-treated soils. Manure addition and the manure + inocula treatment can also be used as a prominent treatment in the restoration, to increase the organic matter content and the microbial activity in soils. The single alga- and microbial inocula treatment was not successful permanently, therefore their use - without adding any parallel organic matter - cannot be recommended.

Investigations of the soil microbial activity showed that the lowest temperature of thermal treatments had resulted a more effective revitalization. The clay-pearl additive increased the persistency and activity of the microbes in the soil. It was also obviously found that the organic additives with or without the microbial inoculations could be used potentially as the best soil revitalization treatments.

Key words: manure, compost, microbes, inoculation, restoration

\section{References}

BIRÓ, B. et al., 1993a. Symbiont effect of Rhizobium bacteria and VAM fungi on Pisum sativum in recultivated mine spoils. Geomicrobiol. J. 11. 275-284.

BIRÓ B. et al., 1993b. Effect of fertilizer on spontaneous Rhizobium infection in Hungarian soils. Agrokémia és Talajtan. 42. 207-212.

BuZÁs, I (Ed.) 1988. Methods of Soil Analysis. Part 1 and 2. (In Hungarian). Mezögazdasági Kiadó. Budapest.

DoubleDAY, G. P., 1974. The reclamation of lands after coal-mining activities. Outlook on Agriculture. 8. 156-162.

INSAM, H. \& DOMSCH, K. H., 1988. Relationships between soil organic carbon and microbial biomass on chronosequences of reclamation sites. Microbial Ecology. 15. $177-188$.

KÁtAI, J., 1999. Changes of soil microbiological parameters in a long-term field experiment. (In Hungarian). Agrokémia és Talajtan. 48. 348-361.

ÖRDÖG, V. \& MÁTÉ, F., 2002. Procedure and possibility for estimating the phosphor availability by algal strains in vitro. (In Hungarian). Agrokémia és Talajtan. 51. (Accepted for publication). 
SCULlion, J., 1992. Re-establishing the life in restored topsoil. Land Degradation and Rehabilitation. 3. 161-168.

SzEGI, J., 1979. Manual for Soil Microbiological Studies (In Hungarian). Mezőgazdasági Kiadó. Budapest. 